\title{
TOURISM DEMAND IN INDONESIA: IMPLICATIONS IN A POST-PANDEMIC PERIOD
}

\author{
Miguel Angel ESQUIVIAS* \\ Airlangga University, Faculty of Economics and Business, Surabaya, Indonesia, e-mail: miguel@ feb.unair.ac.id
}

Lilik SUGIHARTI

Airlangga University, Faculty of Economics and Business, Surabaya, Indonesia, e-mail: sugiharti.lilik@ feb.unair.ac.id

Hilda ROHMAWATI

Airlangga University, Faculty of Economics and Business, Surabaya, Indonesia, e-mail: hildarohmawati24@gmail.com

Bekti SETYORANI

Airlangga University, Faculty of Economics and Business, Surabaya, Indonesia, e-mail: bektisetyorani1995@gmail.com

Angger ANINDITO

Ministry of National Development Planning of Indonesia, Jakarta, Indonesia, e-mail: istasus.anindito@bappenas.go.id

\begin{abstract}
Citation: Esquivias, M.A., Sugiharti, L., Rohmawati, H., Setyorani, B., \& Anindito, A. (2021). TOURISM DEMAND IN INDONESIA: IMPLICATIONS IN A POST-PANDEMIC PERIOD. GeoJournal of Tourism and Geosites, 37(3), 951-958. https://doi.org/10.30892/gtg.37329-731
\end{abstract}

\begin{abstract}
This study uses an autoregressive distributed lag (ARDL) model to investigate the role of incomes, relative price competitiveness, and substitution prices in tourism demand from Indonesia's six largest countries of origin from 2007Q1 to 2019Q4. Income level, competitive prices, and substitution prices significantly impact the demand for tourism in Indonesia. Malaysia, Singapore, Australia, Japan, and India are income elastic, signaling that tourism is a luxury good, but China (normal good). Malaysia and China are price elastic while Japan, India, Singapore, and Australia are less affected by changes in relative prices. Substitute prices may drive tourist to other destinations if the change in prices is large.
\end{abstract}

Key words: tourism demand, COVID-19, international tourism, Indonesia, ARDL, price competitiveness, tourism economics, tourism development

* $* * \quad * \quad * \quad *$

\section{INTRODUCTION}

The rapid growth in the number of inbound tourists from Asia Pacific and Australia to Indonesia shows that the tourism sector is a promising source of income for the country. From 2007 to 2019, arrivals from the top-grossing countries increased sharply. Inflows from China multiplied by nearly 800\%; those from India expanded by $430 \%$; and those from Malaysia grew by almost $273 \%$. Similarly, arrivals from high-income regional partners like Australia, Japan, and Singapore hit more than 3.8 million combined in 2019. By contrast, arrivals from traditional European and American markets expanded at a much lower rate. In the last decade, the government of Indonesia has placed special attention on tourism activities, expecting to increase foreign arrivals to 20 million by 2020 and to increase the contribution of tourism to GDP.

To achieve 20 million foreign tourist arrivals, the government selected 10 strategic destinations coined as the 10 new 'Balis'. The government expects that US\$20 billion on investment would be needed, mainly for infrastructure improvement and promotional campaigns (Muryani et al., 2020). Visa schemes have been relaxed (visa-free for some Asian countries and visa-on-arrival for others). The Ministry of Tourism promoted tourism actively in Australia, India, Japan, South Korea, Malaysia, Singapore, and China via Wonderful Indonesia campaign; established Visit Indonesia Tourism Officer (VITO) operation in the six countries, and participated regularly in tourism exhibitions. There was also virtual reality launched in foreign airports under the Xperience Wonderful Indonesia campaign to feature the 10 new Bali destinations. In addition to that, the Indonesian government launched the Generasi Wonderful Indonesia (GenWi) - a campaign focusing on attracting millennials from Asian countries - since the average age of tourists from Asian countries is below 39 years old. There are also Famtrip events to introduce new destinations for targeted audiences (e.g., tourist agencies, bloggers, media, and event organizers). Most of the promotion efforts are within Asia and the largest European countries (traditional visitors).

Asian countries have become the largest market of Indonesian tourism, strongly driven by the economic growth and higher openness to travel. The boom raises a question about the sustainability of the Asian market. The tourism sector, both private and public, has responded to the fast-growing market with greater investments, but the question remains on the long-term expansion scenarios. Tourism is exposed to shocks (economic, political, social, or health) that may compromise the stability of the sector. The financial crisis in 2008, terrorism attacts in 2002 and 2005, natural disasters, and the

* Corresponding author 
COVID-19 pandemic demonstrates the impacts of such shocks (Muryani et al., 2020; Purwomarwanto and Ramachandran, 2015; Smyth et al., 2009; Song and Lin, 2010; Wahyuningtyas et al., 2019). For example, the COVID-19 pandemic has led to a sharp decrease in tourism arrivals and caused a sharp global economic decline. As countries impose travel restrictions, and as economic prospects continue to fall, recovery in tourism activities would not be easy. This will require support tools that help to resume activities, compensate for the losses, and recover confidence (Bakar and Rosbi, 2020; Korinth and Ranasinghe, 2020).The Indonesian government's initial recovery strategy focuses on domestic tourism while progressively resuming regional Asia Pacific activities. A fiscal stimulus of IDR4.7 trillion for tourism-related activities has been proposed, and a series of travel incentives for promotional campaign and discounts have been rolled out. The measures are substantial because the sector has been hit the hardest by the pandemic.

Despite substantial developments in infrastructure, branding, human resources, and promotion activities in the last decade (Pujiharini and Ichihashi, 2016), the tourism industry is unlikely to rebound as fast as the other sectors. Therefore, it is vital to understand the economic forces needed to bring more tourists to Indonesia. The literature highlights that the major explanatory variables in tourism models include income of tourists, touristic service prices, substitution prices, and exchange rates ( $\mathrm{Li}$ et al., 2005; Peng et al., 2015). The pandemic has caused a reduction in the incomes of foreign tourists. Meanwhile, prices in Indonesia and other countries are adjusting, which is likely to shift the demand for tourism services. International tourism competition will tighten as countries target a quick recovery of the tourism sector by allocating generous support measures. Besides, the Indonesian Rupiah (IDR) has been depreciating against the currency in the six topgrossing countries, which may translate into a competitive advantage.

In 2020, the real GDP growth was $-2.4 \%$ in Australia, -5.4 in Singapore, -5.6\% in Malaysia, $-4.8 \%$ in Japan, and $-8 \%$ in India. China was the only top-grossing country (for the Indonesian tourism) that experienced growth in 2020 (2.3\%). A contraction of GDP implies a fall in disposable income. Additionally, the declining consumer price index in countries like Thailand, Malaysia, Australia, Japan, Singapore, Hong Kong, and some European countries might help them become more price-competitive tourism destinations than Indonesia. Research has shown that incomes and prices are essential elements in demand for tourist arrivals (Barman and Nath, 2019; Gössling et al., 2020; Yazdi and Khanalizadeh, 2017).

The main objective of this study is to investigate to what degree factors like income levels, relative price competitiveness, and substitution prices drive the demand for tourism services in Indonesia. We look at arrivals from the six top-grossing countries. We include a lag variable on tourism arrivals to measure the word-of-mouth effect, an essential driver in tourism demand, and a dummy variable to observe the shock in tourism sector from the global financial crisis in 2008-09. Although previous pandemics (SARS, MERS, and H1N1) triggered a slowdown in international inbound tourists in Indonesia (Kuo et al., 2008), the effects were shorter and smaller than the current COVID-19 (Abiad et al., 2020; Gössling et al., 2020). To investigate the connection between income, price, and tourism arrivals, we use an autoregressive distributed lag (ARDL) model to estimate tourism demand from the six largest topgrossing countries in Asia Pasific: Australia, Singapore, Malaysia, Japan, China, and India. An autoregressive approach includes lag variables to model consumer demand as income and price variables commonly have lagged effects in demand for tourism services (Cheng, 2012). We employ quarterly data from 2007Q1 to 2019Q4.

The ARDL can estimate short and long-term income and price elasticity for the six countries relative to Indonesia, and these are proxies for the role of income and price competitiveness on tourism. Tourism industry is targeted to be a new source of economic growth for the Indonesian economy. Before the COVID-19 pandemic, Indonesia welcomed 16.2 million foreign visitors, contributing US\$17.6 billion in foreign currency in 2019 and supporting more than $10 \%$ of direct and indirect jobs in the country. China, India, Malaysia, and Australia have been dynamic markets (rapid growth); Singapore is less dynamic; and Japan has stagnated. The sector needs a recovery plan to restore jobs, attract foreign exchange, and boost the economy (Gössling et al., 2020; Mahadevan et al., 2017). We expect that competitiveness of the tourism industry in Indonesia is related to the depreciation of IDR and the rapid income growth from the inbound countries, particularly China (Lin et al., 2015). However, aggressive recovery plans to deal with impact of COVID-19 in other coutries of destination may lead to a tighter competition (Abiad et al., 2020; Bakar and Rosbi, 2020). This is because consumer price indexes and the income of tourists are changing.

This study makes the following contributions. First, we extend the literature of tourism demand for Indonesia by providing estimates from the six largest inbound markets. Second, we investigate whether relative prices and alternative prices (a benchmark for foreign competition) explain Indonesia's boom in tourism. Third, we analyze income and price elasticities to reveal preferences towards a touristic destination. Such indicators are crucial for the development of tourism strategies (Peng et al., 2015). Finally, we offer evidence of the effects of the financial crisis in 2008-2009 to illustrate the shock resulting from the COVID-19 pandemic.

\section{MATERIALS AND METHODS}

We estimate tourism demand from the six largest markets, namely Australia, Singapore, Malaysia, Japan, China, and India. An autoregressive distributed lag model (ARDL) is applied to estimate arrivals as a function of income, relative prices, and prices at the alternative countries of destination. Income and prices are fundamental forces in explaining the demand for tourism services (Peng et al., 2015). Rapid growth in disposable income is associated with an expansion in outbound travels, which has been well documented in the Asian context (Barman and Nath, 2019; Lin et al., 2015; Zhu et al., 2018).

Prices in Indonesia are compared with its top competitors' prices in this analysis (Table 1). Competitiveness is considered an important determinant of travel destination choice (Xie and Tveterås, 2020). Competitive prices are linked to exchange-rate fluctuations, which impact tourism arrivals to a large extent (Aalen et al., 2019; Peng et al., 2015). 
Specifically, relative prices capture the cost of living in the destination country relative to the country of origin (Jin and Wang, 2016; Kronenberg et al., 2016), which is often represented by the consumer price index adjusted by exchange rates.

Seetaram et al. (2016) suggest using a price competitiveness index as a more precise indicator for alternative prices. Relative prices do not capture the interaction with the alternative destinations. Meanwhile, such an indicator of alternative prices is needed to capture the competition. The Index for alternative prices that signals a positive relationship with demand indicates that the alternative destinations have more competitive prices, hence they could be substitute destinations (Salleh et al., 2007). On the other hand, negative price competitiveness index means that the alternative countries could be complementary destinations. In previous research the impact of substitution prices on tourism demand vary, as shown in Mediterranean countries (Patsouratis et al., 2005) and Asia (Athanasopoulos et al., 2014; Etzo et al., 2014).

We use quarterly data from 2007Q1 to 2019Q4. A lagged variable for arrivals is included to capture the effect of word-ofmouth, which is assumed to have a significant impact on tourism demand (Chen and Haynes, 2015; Dogru et al., 2017).

Table 1. Top Destination Countries of Indonesia's Main Tourism Partners in 2019 Source: Authors' determination based on tourist arrivals in 2019, the World Tourism Organization

\begin{tabular}{|l|c|c|c|c|c|c|}
\hline & Malaysia & Singapore & China & Australia & Japan & India \\
\hline Top 1 & Thailand & Malaysia & Thailand & New Zeeland & United States & Thailand \\
\hline Top 2 & Singapore & Japan & Japan & United States & France & Singapore \\
\hline Top 3 & Australia & Thailand & Philippines & United Kingdome & Singapore & Malaysia \\
\hline Top 4 & Brunei & Hong Kong & United States & Thailand & Australia & United States \\
\hline
\end{tabular}

Additionally, we incorporate expected shocks in tourism arrivals as an impact of the global financial crisis (GFC) in 2008-09 to capture the impact of unusual events on tourism (Xie and Tveterås, 2020).

To measure tourism activities, we use data on tourism arrivals $\left(Y_{i, t}\right)$ on a quarterly basis from the six selected countries (quarter $t$ from country $i$ ). A number of studies have concluded that the number of tourist arrivals is a suitable proxy for tourism demand (Adeola et al., 2018; Cheng, 2012). We employ GDP as a proxy for the tourists' income level, with data sourced from the World Bank. The tourism price in Indonesia relative to country $i$ at time $t$ is indicated by the Consumer Price Index $(\mathrm{CPI})$ and estimated as $\mathrm{RP}_{\mathrm{i}, \mathrm{t}}=\left(\mathrm{CPI}_{\mathrm{IDN}, \mathrm{t}} / \mathrm{EXR}_{\mathrm{IDN}, \mathrm{t}}\right) /\left(\mathrm{CPI}_{\mathrm{it}} / \mathrm{EXR}_{\mathrm{it}}\right)$, where $\mathrm{CPI} \mathrm{IND}_{\mathrm{Is}} \mathrm{CPI}$ of Indonesia and $\mathrm{CPI}_{\mathrm{i}}$ are and the inbound country $(i)$. Data on exchange rates of each country are obtained from the World Bank $\left(\mathrm{EXR}_{\mathrm{it}}\right)$ reported in USD. The indicator on Substitute Prices (SP) is proposed by the top tourism destinations of each country $i$ (Table 1) and computed according to Dogru et al. (2017). All datasets used are quarterly.

$$
S P_{\mathrm{i}_{1} \mathrm{t}}=C P I_{I D N_{0} t} /\left[\left(C P I_{T 1}+C P I_{T 2}+C P I_{T 3}+C P I_{T 4}\right)_{t} \times 25 \%\right] \times E X R
$$

where $C P I_{I D N_{-} t}$ represents the consumer price of Indonesia at period $t, C P I_{T 1_{23,4}}$ are CPI of leading four alternative destination country, and EXR is the exchange rate of Indonesia.

To find the suitable ARDL model (lags) for each of the six countries in the study, the Akaike (AIC) and the Schwartz (SIC) information criteria selection tool is employed. The variables are first tested for stationarity, followed by the cointegration analysis using the ARDL bound test proposed by (Pesaran and Shin, 1998). The ARDL model addresses the cointegrating relationship between variables under $\mathrm{I}(0)$ and/or $\mathrm{I}(1)$. The bound test, which is employed to assess cointegration, helps to identify if a stable and long-run relationship exists between the variables proposed to estimate tourism demand. The ARDL model is specified in Eq (2) as:

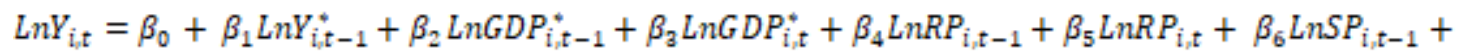

$$
\begin{aligned}
& \beta_{7} \operatorname{LnSP_{\mathrm {i},\mathrm {t}}}+G F C_{2009}+\varepsilon_{\mathrm{t}}
\end{aligned}
$$

Where $\mathrm{Y}_{\mathrm{i}, \mathrm{t}-1}$ represents tourism arrivals from country $i$ and $t$ refers to the time. GDP $\mathrm{i}_{\mathrm{i}, \mathrm{t}}$ refers to the gross domestic product of country $i$ at time $t$. RP indicates consumer price index of Indonesia relative to the price of country $i$ at time $t$, and SP refers to substitute price. A variable dummy is used to cover the global financial crisis of 2008-09 $(G F C)$. $\varepsilon_{t}$ is the error term.

The ARDL model is tested using the Error Correction Model (ECM) for cointegration. After the cointegration test, the short and long-run impacts of tourism demand are estimated. Once the ECM terms are generated, the error correction is calculated following the expression:

$$
\Delta Y_{\mathrm{i}, t}=\pi_{\mathrm{i} 0}+\pi_{\mathrm{i} G D P} \Delta G D P_{\mathrm{i}, \mathrm{t}}+\pi_{\mathrm{iR} P} \Delta R P_{\mathrm{i}, \mathrm{t}}+\pi_{\mathrm{i} S p} \Delta S P_{\mathrm{i}, \mathrm{t}}+\Delta G F C_{2009}+\pi_{\mathrm{i \varepsilon}} \hat{\varepsilon}_{\mathrm{i}, t-1}+\tau_{\mathrm{it}}
$$

The first-difference operator is denoted by $\Delta$, and the error term is capture in $\tau_{i t} . \hat{\varepsilon}_{\mathrm{i}, t-1}$ denotes the ECM term computed as follows:

$$
\hat{\varepsilon}_{\mathrm{i} t \mathrm{t}-1}=\beta_{0}-\beta_{1} Y_{\mathrm{i}, \mathrm{t}-1}-\beta_{2} G D P_{\mathrm{i}, \mathrm{t}-1}-\beta_{4} R P_{\mathrm{i}, \mathrm{t}-1}-\beta_{6} S P_{\mathrm{i}_{j}, \mathrm{t}-1}-G F C_{2009}
$$

The short-run terms on Eq (3) do not have direct structural interpretation, more often are interpreted as transitory effects (Cheng, 2012). The lagged variables in Eq (4) capture the long-run relationships. To interpret the results as elasticities, a ratio of $-\beta_{2} / \beta_{1}$ indicates income elasticity, $-\beta_{4} / \beta_{1}$ a price elasticity, and $-\beta_{6} / \beta_{1}$ cross-price elasticity. It is expected to have positive income elasticities and negative price elasticity (relative price), while substitute price might take either positive or negative values (cross-price elasticity).

\section{RESULTS AND DISCUSSION}

Tourism arrivals in Indonesia had increased substantially (Figure 2). Uniquely rapidly is the increase in arrivals from Asia Pacific and Australia markets, indicating that geographical (regional) proximity is crucial to Indonesia. The rapid 
growth in income from emerging Asian markets is also a key driver of tourism sector. Another factor is price competitiveness, either via low local prices as measured by CPI relative to partner countries', or via depreciated IDR (in general terms) against partner countries' currencies (Figure 1). Compared to other Asian countries (e.g., Japan, China, South Korea, Singapore, Malaysia, Thailand, and India), Indonesia reports a lower score in the 2019 Travel and Tourism Competitiveness Index (TTCI). We follow Pesaran et al. (2001) for the ARDL estimation as it offers the advantage of admitting different integration orders on the relations among variables, either $\mathrm{I}(0)$ or $\mathrm{I}(1)$. Earlier studies have indicated the suitability of this cointegration approach for tourism demand models (Lin et al., 2015; Song and Lin, 2010). ARDL models assumes that the variable must not be stationary at I (II) because it can produce spurious regressions (Pesaran et al., 2001).

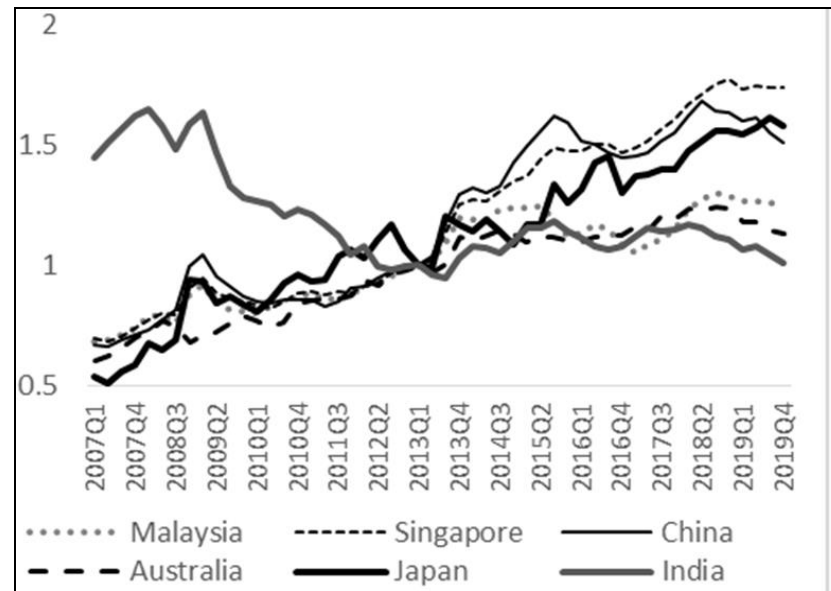

Figure 1. Relative Prices Indonesia - Partners

(Source; Data from World Bank and Statistics Indonesia)

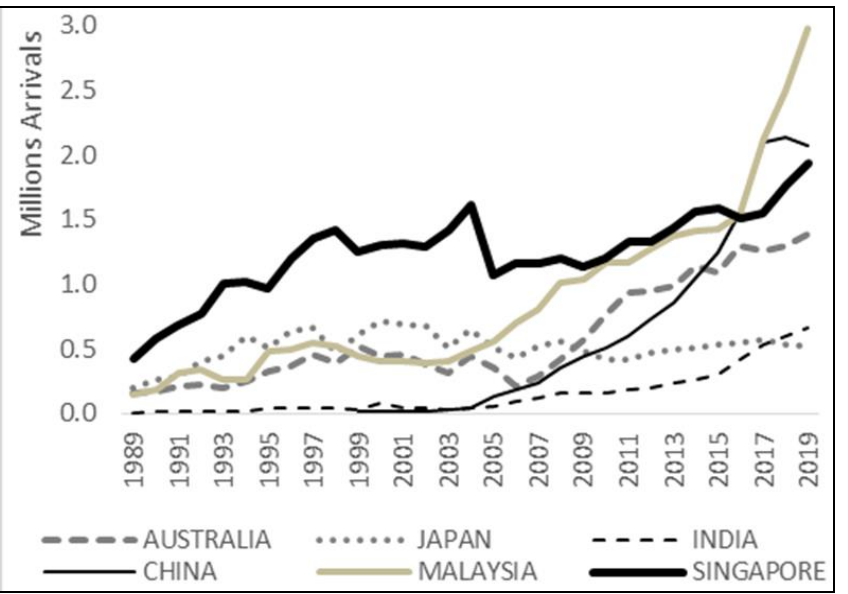

Figure 2. Tourism Arrivals Top Six count

(Source: Data from Statistics Indonesia)

The unit root test with an Augmented-Dickey Fuller (ADF) is performed to ensure that there are no stationary variables at the second difference level I (II) in the model (Rehman et al., 2020). This study indicates that tourist arrivals (Y) variable in all countries is stationary at the first-difference level, except for Australia, which is stationary at the level. Meanwhile, the GDP, substitution price (SP), and relative price (RP) variables, all are stationary at the first difference. The dummy variable for global financial crisis (GFC) is stationary at the level and the first difference. This means that none of the variables presents a unit root problem and stationary at the second difference, suggesting that the data are qualified to employ the ARDL approach and avoid spurious regression analysis (Pesaran et al., 2001; Rehman et al., 2020).

Table 2. Unit Root Test

\begin{tabular}{|c|c|c|c|c|c|}
\hline Countries & $\begin{array}{c}\text { Stationary } \\
\text { Level }\end{array}$ & LnY & lnGDP & $\operatorname{lnSP}$ & $\ln R P$ \\
\hline \multirow[t]{2}{*}{ Malaysia } & Level (0) & 0.46 & 0.31 & -0.89 & -1.76 \\
\hline & First Diff (I) & $-3.27 * *$ & $-6.63 * * *$ & $-4.97 * * *$ & $-5.56 * * *$ \\
\hline \multicolumn{2}{|c|}{ Selected Stationary Level } & $\mathrm{I}(\mathrm{I})$ & $\mathrm{I}(\mathrm{I})$ & $\mathrm{I}(\mathrm{I})$ & $\mathrm{I}(\mathrm{I})$ \\
\hline \multirow[t]{2}{*}{ Singapore } & Level (0) & 0.12 & -0.44 & -1.02 & -1.16 \\
\hline & First Diff (I) & $-3.18 * *$ & $-2.60 *$ & $-5.24 * * *$ & $-5.21 * * *$ \\
\hline \multicolumn{2}{|c|}{ Selected Stationary Level } & $\mathrm{I}(\mathrm{I})$ & $\mathrm{I}(\mathrm{I})$ & $\mathrm{I}(\mathrm{I})$ & $\mathrm{I}(\mathrm{I})$ \\
\hline \multirow[t]{2}{*}{ China } & Level (0) & -2.96 & -1.15 & -1.01 & -1.76 \\
\hline & First Diff (I) & $-3.78 * * *$ & $-2.69 *$ & $-5.17 * * *$ & $-4.21 * * *$ \\
\hline \multicolumn{2}{|c|}{ Selected Stationary Level } & $\mathrm{I}(\mathrm{I})$ & $\mathrm{I}(\mathrm{I})$ & $\mathrm{I}(\mathrm{I})$ & $\mathrm{I}(\mathrm{I})$ \\
\hline \multirow[t]{2}{*}{ Australia } & Level (0) & $-3.29 * *$ & -0.71 & -0.99 & -2.39 \\
\hline & First Diff (I) & -2.47 & $-3.42 * *$ & $-5.10 * * *$ & $-6.19 * * *$ \\
\hline \multicolumn{2}{|c|}{ Selected Stationary Level } & $\mathrm{I}(0)$ & I(I) & $\mathrm{I}(\mathrm{I})$ & $\mathrm{I}(\mathrm{I})$ \\
\hline \multirow[t]{2}{*}{ Japan } & Level (0) & -1.67 & -0.84 & -0.97 & -2.28 \\
\hline & First Diff (I) & $-3.99 * * *$ & $-3.99 * * *$ & $-5.01 * * *$ & $-3.50 * *$ \\
\hline \multicolumn{2}{|c|}{ Selected Stationary Level } & $\mathrm{I}(\mathrm{I})$ & $\mathrm{I}(\mathrm{I})$ & $\mathrm{I}(\mathrm{I})$ & $\mathrm{I}(\mathrm{I})$ \\
\hline \multirow[t]{2}{*}{ India } & Level (0) & 0.48 & 1.31 & -0.99 & -1.1 \\
\hline & First Diff (I) & $-3.15 * *$ & $-4.77 * * *$ & $-5.19 * * *$ & $-5.38 * * *$ \\
\hline \multicolumn{2}{|c|}{ Selected Stationary Level } & $\mathrm{I}(\mathrm{I})$ & $\mathrm{I}(\mathrm{I})$ & $\mathrm{I}(\mathrm{I})$ & $\mathrm{I}(\mathrm{I})$ \\
\hline
\end{tabular}

Additionally, we implement bound tests to determine cointegration relationships. The bound test coefficient ( $\mathrm{F}$ Statistic) is significant if the value is above the critical upper bound value (Pesaran et al., 2001; Srinivasan et al., 2012). The results from the bound test indicate that the proposed models for each country have an F-statistic value above the upper bound at the 5\% significance level or better (Table 3). This result rejects the null hypothesis (no cointegration) and accepts the alternative hypothesis (cointegration) so that there is a long and short run relationship between the independent variable and the dependent variable. The ARDL estimation involves the Unrestricted Error Correction
Table 3. Bound Test

\begin{tabular}{|c|r|r|c|r|r|r|}
\hline Model & Malaysia & Singapore & China & Australia & Japan & India \\
\hline $\begin{array}{c}\text { Model } \\
1\end{array}$ & $\begin{array}{r}9.735 \\
* * *\end{array}$ & $6.188 * * *$ & $4.440 * *$ & $6.779 * * *$ & $\begin{array}{r}4.784 \\
* * *\end{array}$ & $\begin{array}{r}9.179 \\
* * *\end{array}$ \\
\hline $\begin{array}{c}\text { Model } \\
2\end{array}$ & $\begin{array}{r}12.597 \\
* * *\end{array}$ & 22.101 & 4.693 & $6.967 * * *$ & $\begin{array}{r}5.643 \\
* * *\end{array}$ & $\begin{array}{r}16.391 \\
* * *\end{array}$ \\
\hline
\end{tabular}

Notes: $*, * *, * * *$ indicate $10 \%, 5 \%, 1 \%$ significance, respectively. The level of significance is based on the lower and upper bounds. $10 \%$ (lower bound is 2.37 and upper bound is 3.2), 5\% (lower bound is 2.79 and upper bound is 3.67 ), $1 \%$ (lower bound is 3.65 and upper bound is 4.66 )

Table 4. Error Correction Term

\begin{tabular}{|c|r|r|r|r|r|r|}
\hline Model & Malaysia & Singapore & China & Australia & Japan & India \\
\hline $\begin{array}{c}\text { Model } \\
1\end{array}$ & -0.241 & $-2.818 * * *$ & -1.020 & -0.276 & -0.992 & -0.362 \\
$* * *$ & & $* * *$ & $* * *$ & $* * *$ \\
\hline $\begin{array}{c}\text { Model } \\
2\end{array}$ & -0.445 & $-1.415 * * *$ & -1.439 & -0.768 & -1.059 & -1.147 \\
$* * *$ & & $* * *$ & $* * *$ & $* * *$ \\
\hline
\end{tabular}

Notes: *,**, *** indicate $10 \%, 5 \%$, and $1 \%$ significance, respectively

otes: The number in the table are the t-statistic. *,**,*** indicate $0 \%, 5 \%$, and $1 \%$ significance, respectively. I( 0 ) indicates stationary at $0 \%, 5 \%$, and $1 \%$ significance, respectively. $\mathrm{I}(0)$ in
evel and $\mathrm{I}(\mathrm{I})$ indicates stationary at first difference 
Model (UECM). The error correction term (ECT hereafter) indicates the adjustment rate in response to deviances from the long-run equilibrium path. We accept the ECT when the value is negative and significant. Table 4 shows the value of ECT for each model in all countries. The results of this study indicate a negative and significant ECT with a significance level of $1 \%$, in line with Banerjee et al. (1998). A significant ECT result strengthens the results of the bounds test (Onafowora and Owoye, 2012). The ECT for the case of Malaysia indicates that inbound arrivals in the current quarter will adjust towards the equilibrium by -0.445 of the deviation from the previous quarter.

Arrivals from Australia will adjust towards the equilibrium at the speed of -0.768 from the previous quarter (relatively fast speed of adjustment). For the cases where the ECT is between -1 and -2 , the ECT fluctuates around the long-run equilibrium path before convergence, as noted in Narayan and Smyth (2006).

Table 5 shows the results of the classical assumption tests as a diagnostic test. The results show that the model does not have classical assumption problems and has a high bound coefficient. A model with high bounds coefficient has high cointegration (Nkoro and Uko, 2016), thus forming a strong statistical and economic base for the ECM-ARDL model.

Table 5. Diagnostic Tests

\begin{tabular}{|l|c|c|c|c|c|c|}
\hline & Malaysia & Singapore & China & Australia & Japan & India \\
\hline Heteroscedasticity & 0.572 & 0.141 & 0.201 & 0.815 & 0.364 & 0.153 \\
\hline Autocorrelation & 0.106 & 0.313 & 0.101 & 0.539 & 0.062 & 0.722 \\
\hline Normality & 0.974 & 0.552 & 0.650 & 0.428 & 0.792 & 0.818 \\
\hline
\end{tabular}

\section{Tourism Demand Model}

Table 6 shows the estimates for the ARDL model. The upper part of Table 6 presents the estimated results for the short run and the lower part for the long run. Although the short-run estimates do not have direct structural interpretation, they offer relevant information on transition on the variables. In the short run, the coefficient for lagged effect from arrivals has the expected positive sign for China and Australia. It indicates a significant effect of word-of-mouth, which has been captured in tourism demand models before (Seetaram et al., 2016; Xie and Tveterås, 2020). The loyalty of tourists from China and Australia suggests that the effect of word-of-mouth might be an important driver of tourism from those countries, in line with earlier studies (Muryani et al., 2020). Word-of-mouth effects highlight the importance of creating positive touristic experiences.

A new tourist may depend on recommendations from a tourist with a previous experience visiting Indonesia. To optimize customer experience, Indonesia has invested in infrastructure since 2014, which is aimed at contributing to better accessibility and connectivity for tourists. Improvements in infrastructure often positively impact tourism (Chen and Haynes, 2015). Meanwhile, Malaysia is the largest inbound tourist market for Indonesia (almost 3 million arrivals in 2019). The coefficient of lagged arrivals from Malaysia has a negative effect on tourism demand, likely as the number of arrivals from Malaysia experience substantial fluctuation although there is a positive trend in the number of visits. In tourism demand models, income helps to approximate the purchasing power of tourists. We find that income has a positive impact both in the short run and in the long run for Malaysia and Japan. For Singapore, China, Australia, and India, income has a negative effect on tourism demand in Indonesia in the short run.

A negative coefficient does not mean that income impacts negatively. Instead, it reflects transitory effects or even that changes in quarterly income do not positively influence the decision to travel to Indonesia. Still, in the long run, income is a crucial driver for tourism demand in Indonesia for all partner countries. Only the results for Australia are not significant. For China, the coefficient is positive and significant, although lower than one, suggesting that tourism in Indonesia may be considered a non-luxurious service. For Malaysia, Singapore, Japan, and India, the income coefficient is larger than (or close to) one, signaling that tourism is a luxury good and responds strongly to increasing income.

Table 6. Results for the ARDL Estimation

\begin{tabular}{|c|c|c|c|c|c|c|}
\hline \multicolumn{7}{|c|}{ Short Run } \\
\hline \multirow{2}{*}{ Variables } & \multicolumn{6}{|c|}{ Coefficients } \\
\hline & Malaysia & Singapore & China & Australia & Japan & India \\
\hline $\mathrm{D}(\mathrm{LNY}(-1))$ & $-0.519 * * *$ & & $0.557 * *$ & $0.327 * * *$ & & \\
\hline $\mathrm{D}(\mathrm{LNY}(-2))$ & $-0.227 * *$ & & 0.116 & 0.106 & & \\
\hline $\mathrm{D}(\mathrm{LNY}(-3))$ & $-0.443 * * *$ & & 0.0005 & $-0.280 * *$ & & \\
\hline D(LNRGDP) & $0.732 *$ & -0.0007 & $-0.502 * *$ & -0.813 & $1.181 * * *$ & -0.014 \\
\hline D(LNRGDP(-1)) & & $-1.094 * * *$ & $-0.799 * * *$ & $-2.379 * * *$ & $-1.336 * * *$ & $-2.570 * * *$ \\
\hline $\mathrm{D}($ LNRGDP(-2)) & & -0.382 & $0.791 * * *$ & -0.101 & $-2.537 * * *$ & $-0.951 * *$ \\
\hline D(LNRGDP(-3)) & & -0.276 & & $1.181 * *$ & $1.036^{*}$ & $-1.387 * * *$ \\
\hline $\mathrm{D}(\mathrm{LNSP})$ & 0.132 & -0.342 & 1.188 & $-0.626 * *$ & $1.0397 * * *$ & 0.038 \\
\hline $\mathrm{D}(\operatorname{LNSP}(-1))$ & & $2.171 * * *$ & $-2.888 * *$ & $-0.516 * *$ & & $-1.730 * * *$ \\
\hline $\mathrm{D}(\mathrm{LNSP}(-2))$ & & $1.870 * * *$ & & $-0.467 * *$ & & $-1.247 * * *$ \\
\hline $\mathrm{D}(\operatorname{LNSP}(-3))$ & & $0.618^{* * *}$ & & $-0.704 * * *$ & & $-1.197 * * *$ \\
\hline $\mathrm{D}(\mathrm{LNRP})$ & -0.529 & 0.407 & 0.351 & 0.415 & $-0.787 * * *$ & -0.358 \\
\hline $\mathrm{D}(\operatorname{LNRP}(-1))$ & $1.021 * * *$ & $-1.580 * * *$ & $2.163^{*}$ & & & $1.277 * * *$ \\
\hline $\mathrm{D}(\operatorname{LNRP}(-2))$ & $0.593 * *$ & $-1.001 * *$ & & & & $0.826 * *$ \\
\hline $\mathrm{D}(\mathrm{GFC})$ & 0.069 & $-0.431 * * *$ & $-0.320 * *$ & -0.0197 & $-0.103 *$ & -0.148 \\
\hline $\mathrm{D}(\mathrm{GFC}(-1))$ & $-0.294 * * *$ & & $0.233 * * *$ & $0.192 * *$ & & 0.065 \\
\hline $\mathrm{D}(\mathrm{GFC}(-2))$ & $-0.267 * * *$ & & & $0.109 *$ & & $0.142 * *$ \\
\hline $\mathrm{D}(\mathrm{GFC}(-3))$ & & & & $0.174 * * *$ & & $0.127 * *$ \\
\hline \multicolumn{7}{|c|}{ Long Run } \\
\hline \multirow{2}{*}{ Variables } & \multicolumn{6}{|c|}{ Coefficients } \\
\hline & Malaysia & Singapore & China & Australia & Japan & India \\
\hline LNRGDP & $4.894^{* * * *}$ & $0.999^{* * * *}$ & $0.771^{* * * *}$ & -0.081 & $2.468^{* * * *}$ & $2.171^{* * *}$ \\
\hline LNSP & 0.122 & $-1.123^{* * * * *}$ & $2.402^{* * * *}$ & $0.223^{*}$ & $0.334^{* * * * *}$ & $0.794^{* * * *}$ \\
\hline LNRP & $-1.941^{* * *}$ & $1.139^{* *}$ & $-1.577^{* * * *}$ & $0.525^{*}$ & $-0.354^{* * * *}$ & $-0.494^{* * *}$ \\
\hline LNGFC & $0.746^{* * * *}$ & 0.059 & $-0.264^{* * * *}$ & $-0.417^{\text {***** }}$ & 0.029 & $0.362^{\text {***** }}$ \\
\hline $\mathrm{C}$ & $-33.189^{* * * *}$ & 1.515 & $-7.287^{\text {***** }}$ & 6.665 & -35.7401 & $-30.3796^{* * * *}$ \\
\hline
\end{tabular}

Note: *,***** indicate $10 \%, 5 \%$, and $1 \%$ significance respectively; $\mathrm{C}$ is $\beta_{0}$ or constant 
A point worth noting is the income effect for Malaysia, Japan, and India may be a threat to recovery as the GDP in all three countries contracted in 2020 and might slowly recover through 2021. In addition, Indonesia is a "sun-lust" destination for Japanese and Australian tourists who mainly travel to Bali. As the interests of many Australians are changing (Seetaram et al., 2016) and Japan is a stagnant market, it imposes a challenge for Indonesia in the recovery period. As for substitute prices, in the short run, Singapore and Japan show a positive coefficient, indicating that an adjustment in relative prices of Indonesia versus main competitors may make potential tourists opt for alternative destinations. Price competitiveness is fundamental for Indonesia and arrivals may drop if prices are no longer at a competitive edge. By contrast, the negative figure in Australia, China, and India in the short run implies that they are complementary to Indonesia as a tourism destination.

This means that improvements in alternative destinations' competitiveness may work in favor of Indonesia. In the post-pandemic period, Indonesia could capitalize on the popularity of the neighboring Asian countries such as Malaysia, Thailand, and Singapore. Substitution prices have a positive effect in the short run for Singapore. It suggests that as alternative destinations become more price-competitive, Singaporeans might prefer traveling to top alternative destinations (Malaysia, Japan, Thailand, and Hong Kong) to visiting Indonesia. Nevertheless, in the long run, a negative sign in the substitution proces suggests that Singaporeans may consider Indonesia as complementary destinations to Malaysia, Japan, Thailand, and Hong Kong (top destinations for Singaporean travelers).

On the other hand, for China, Australia, and India, the coefficient of substitution price signals that top alternative destinations may be substitutes for Indonesian tourism in the long run but complementary in the short run. Meanwhile, for Japanese tourists, the positive and significant coefficient suggests that changes in prices in top destinations may encourage the Japanese to travel to alternative destinations rather than to Indonesia. The coefficient of relative prices for Malaysia, China, and India in the short run has a positive effect but, in the long run, has a negative impact on tourism demand in Indonesia. Our results are in line with Wang (2009), who noted that price increases might not necessarily change the willingness to travel in the short run. In the long run, the relative prices have the expected sign indicating a decrease in tourism demand as prices in Indonesia increase relative to the country of origin.

The effect of the relative prices for tourists from Japan is negative both in the short run and in the long run. These results are in line with theory and previous research that increasing prices can reduce demand (Dogru et al., 2017; Song and Lin, 2010). The relative prices for tourists from Singapore show a negative effect in the short run. Nevertheless, the impact of relative prices for tourists from Singapore and Australia in the long term is positive, likely as Singaporeans and Australians have a higher standard of living compared to Indonesia so that an increase in prices does not reduce demand from these two countries (Muryani et al., 2020; Wasiaturrahma and Rohmawati, 2021).

Interestingly, the coefficient of the relative price is less than one for Australia, Japan, and India, indicating that they are inelastic. As such, increases in prices may not affect the demand for tourism services. Promotion efforts, improvements in quality, and service experience might be more important for tourists from Australia, Japan, and India. By contrast, China, Malaysia, and Singapore have a positive price elasticity, which means that higher prices in Indonesia may discourage tourists from visiting. Although relative prices have a negative effect on tourists from Malaysia and China, arrivals continue to increase. Prices of tourism services seem to be relatively cheap for the Chinese, so they may not substantially affect tourists' decisions (Xie and Tveterås, 2020). Other non-price aspects, like improvements in connectivity, access, promotion, and language, might be an important determinant of tourist arrivals (Kronenberg et al., 2016). Non-price aspects may help to explain why China remains the fastest growing tourism market for Indonesia.

The different reactions in prices among nationalities suggest that promotion policies directed to Singapore and Australian tourists may improve access, quality, experience, safety, and other non-price-related aspects. To some degree, Japanese and Indians may also allow increases in prices as they are price inelastic. Additionally, for Malaysians and Chinese, tourism efforts should consider price-related policies that may help to reactive tourism flows in the long run. A combination of achieving competitive prices and increase value perception appears to be equally important, in line with previous studies (Barman and Nath, 2019; Kim et al., 2018; Yazdi and Khanalizadeh, 2017).

Both relative and substitute prices suggest that Indonesia has relatively strong competitiveness in prices. On the one hand, main tourist inbound countries are not highly sensitive to relative prices (Muryani et al., 2020). On the other hand, Indonesia may attract tourists from markets experiencing a loss in price competitiveness. Still, the coefficients of price substitution are relatively small, signaling that gains on tourism arrivals from improving price competitiveness may be small. By contrast, becoming a substitute market may require substantial promotion efforts and severe improvements in connectivity, access, and progress on quality (Ollivaud and Haxton, 2019).

The global financial crisis (GFC) coefficient has a negative impact on tourism demand in Indonesia for tourists from Malaysia, Singapore, China, and Japan (short-run impacts). The crisis had a positive impact on arrivals from Australia and India in the short run. Only tourism from China and Australia was greatly affected in the long run. The effects from the GFC for Malaysia in the short-run were a $-34 \%$ decrease in arrivals. The impact in percentage terms is calculated from (exp (0.294) - 1) x 100). For the other five countries, a negative impact is - 53\% for Singapore, - $37 \%$ for China, and $-10 \%$ for Japan, while positive effects are recorded in Australia (21\% and India (15\%).

The shocks indicate that tourism activities may converge to equilibrium post-shock, in line with (Muryani et al., 2020; Wang, 2009). A positive aspect is that most of the negative impacts are short term. By contrast, China and Australia, which are reported having a negative impact back in 2009, have been less affected by the pandemic in 2020 than other economies. This suggests that focusing efforts on Australia, India, and China in the short run may help the recovery process. In the long run, Malaysia, Singapore, and Japan may rebound to pre-pandemic levels. 
To expedite the recovery, the stakeholders in Indonesia's tourism sector can maintain prince competitiveness and support the quality of services. Competitive prices are certainly an edge in tourism services in Indonesia, likely fueled by a depreciation of the IDR. Still, in the long run, a loss in price competitiveness, coupled with an improvement of prices in alternative markets, might compromise the dynamic growth of tourism in Indonesia.

\section{CONCLUSION}

The purpose of this study is to estimate a tourism demand model as a function of incomes, relative prices, substitution prices, and the global financial crisis in 2009. We look at the six top-grossing countries for Indonesia, employing quarterly data from 2007Q1 to 2019Q4. An autoregressive distributed lag model is applied to estimate tourism demand together with an Error Correction Model. The results indicate that income level, relative prices, and substitute prices are important determinants in explaining tourism inflows in Indonesia in both the short and long run. For Malaysia, Singapore, Japan, and India, income is elastic, signaling that Indonesia is a luxury good. For China, income plays a positive impact on arrivals but suggests that Indonesia's tourism is a normal good. Malaysia and China are price elastic; while for Japan and India, this is not the case. Singapore and Australia are inelastic towards relative prices, confirming that Indonesia offers substantially lower prices than services in the two countries.

As for substitute prices, in the long run, improvement in prices in alternative destinations may influence tourists' decisions from all origins to travel somewhere else, except Singapore. Only Singapore signals that improvements in price competitiveness in alternative markets may lead to complementarity. Nevertheless, the coefficients of substitute destinations are low for all but China, suggesting that the negative impact on arrivals due to improvements of prices abroad may be relatively small. As such, it indicates that Indonesia remains an attractive tourist destination with price competitiveness. The global financial crisis negatively affects inbound tourists from China and Australia, but interestingly, it increases visitors from Malaysia and India. The weakening of the IDR may strengthen Indonesia's price competitiveness during the global financial crisis (2008-2009).

As the government of Indonesia aims at boosting the economy through tourism, tourism promotion should be directed in specific ways to each market. Indonesia may benefit from competitive prices and a weak currency on the post-pandemic time, nevertheless if the disposable income of foreign tourists drop substantially it may cancel out the gains from competitive relative prices. The markets in Malaysia, Japan, and India may take a more extended period to be restored as these countries are facing a decrease in disposable income and a large income elasticity. Luxurious goods in times of shocks may not become a priority. Singapore, China, and Australia could resume trips to Indonesia more quickly than the other countries. Additionally, the perception of Indonesia as a low-priced tourism destination for Singaporeans and Australians may reinforce the income effect. Although China is the less damaged by the pandemic, Chinese travelers may prefer alternative destinations over Indonesia if substitute destinations become more pricecompetitive. As governments around the world may focus on attracting Chinese tourists, price competitiveness will be vital. Indonesia could capitalize its substantially low relative price compared to China and alternative markets.

\section{Acknowledgement}

The author(s) wished to thank Universitas Airlangga for financial support under the Research Grant "Hibah Riset Mandat Khusus Covid 19 Tahun 2020".

\section{REFERENCES}

Aalen, P., Iversen, E.K., \& Jakobsen, E.W. (2019). Exchange rate fluctuations and demand for hotel accommodation: Panel data evidence from Norway. Scandinavian Journal of Hospitality and Tourism, 19(2), 210-225. https://doi.org/10.1080/15022250.2018.1482566

Abiad, A., Arao, M., Dagli, S., Ferrarini, B., Noy, I., Osewe, P., Pagaduan, J., Park, D., \& Platitas, R. (2020). The Economic Impact of the COVID-19 Outbreak on Developing Asia [ADB Briefs]. Asian Development Bank. https://doi.org/10.22617/BRF200096

Adeola, O., Boso, N., \& Evans, O. (2018). Drivers of international tourism demand in Africa. Business Economics, 53(1), 25-36. https://doi.org/10.1057/s11369-017-0051-3

Athanasopoulos, G., Deng, M., Li, G., \& Song, H. (2014). Modelling substitution between domestic and outbound tourism in Australia: A system-of-equations approach. Tourism Management, 45, 159-170. https://doi.org/10.1016/j.tourman.2014.03.018

Bakar, N.A., \& Rosbi, S. (2020). Effect of Coronavirus disease (COVID-19) to tourism industry. International Journal of Advanced Engineering Research and Science, 7(4), 189-193. https://doi.org/10.22161/ijaers.74.23

Banerjee, A., Dolado, J., \& Mestre, R. (1998). Error-correction Mechanism Tests for Cointegration in a Single-equation Framework. Journal of Time Series Analysis, 19(3), 267-283. https://doi.org/10.1111/1467-9892.00091

Barman, H., \& Nath, H.K. (2019). What determines international tourist arrivals in India? Asia Pacific Journal of Tourism Research, 24(2), 180-190. https://doi.org/10.1080/10941665.2018.1556712

Chen, Z., \& Haynes, K.E. (2015). Impact of high-speed rail on international tourism demand in China. Applied Economics Letters, 22(1), 57-60. https://doi.org/10.1080/13504851.2014.925043

Cheng, K.M. (2012). Tourism demand in Hong Kong: Income, prices, and visa restrictions. Current Issues in Tourism, 15(3), 167-181. https://doi.org/10.1080/13683500.2011.569011

Dogru, T., Sirakaya-Turk, E., \& Crouch, G.I. (2017). Remodeling international tourism demand: Old theory and new evidence. Tourism Management, 60, 47-55. https://doi.org/10.1016/j.tourman.2016.11.010

Etzo, I., Massidda, C., \& Piras, R. (2014). Migration and outbound tourism: Evidence from Italy. Annals of Tourism Research, 48, 235249. https://doi.org/10.1016/j.annals.2014.07.002

Gössling, S., Scott, D., \& Hall, C.M. (2020). Pandemics, tourism and global change: A rapid assessment of COVID-19. Journal of Sustainable Tourism, 1-20. https://doi.org/10.1080/09669582.2020.1758708 
Jin, X., \& Wang, Y. (2016). Chinese Outbound Tourism Research: A Review. Journal of Travel Research, 55(4), 440-453. https://doi.org/10.1177/0047287515608504

Kim, J., Lee, C.K., \& Mjelde, J.W. (2018). Impact of economic policy on international tourism demand: The case of Abenomics. Current Issues in Tourism, 21(16), 1912-1929. https://doi.org/10.1080/13683500.2016.1198307

Korinth, B., \& Ranasinghe, R. (2020). Covid-19 pandemic's impact on tourism in Poland in March 2020. GeoJournal of Tourism and Geosites, 31(3), 987-990. https://doi.org/10.30892/gtg.31308-531

Kronenberg, K., Fuchs, M., Salman, K., Lexhagen, M., \& Höpken, W. (2016). Economic effects of advertising expenditures - a Swedish destination study of international tourists. Scandinavian Journal of Hospitality and Tourism, 16(4), 352-374. https://doi.org/10.1080/15022250.2015.1101013

Kuo, H.I., Chen, C.C., Tseng, W.C., Ju, L.F., \& Huang, B.W. (2008). Assessing impacts of SARS and Avian Flu on international tourism demand to Asia. Tourism Management, 29(5), 917-928. https://doi.org/10.1016/j.tourman.2007.10.006

Li, G., Song, H., \& Witt, S.F. (2005). Recent Developments in Econometric Modeling and Forecasting. Journal of Travel Research, 44(1), 82-99. https://doi.org/10.1177/0047287505276594

Lin, V. S., Liu, A., \& Song, H. (2015). Modeling and Forecasting Chinese Outbound Tourism: An Econometric Approach. Journal of Travel \& Tourism Marketing, 32(1-2), 34-49. https://doi.org/10.1080/10548408.2014.986011

Mahadevan, R., Amir, H., \& Nugroho, A. (2017). Regional impacts of tourism-led growth on poverty and income inequality: A dynamic general equilibrium analysis for Indonesia. Tourism Economics, 23(3), 614-631. https://doi.org/10.5367/te.2015.0534

Muryani, Permatasari, M.F., \& Esquivias, M.A. (2020). Determinants of Tourism Demand in Indonesia: A Panel Data Analysis. Tourism Analysis, 25(1), 77-89. https://doi.org/10.3727/108354220X15758301241666

Narayan, P.K., \& Smyth, R. (2006). What determines migration flows from low-income to high-income countries? An empirical investigation of Fiji-Us migration 1972-2001. Contemporary Economic Policy, 24(2), 332-342. https://doi.org/10.1093/cep/byj019

Nkoro, E., \& Uko, A.K. (2016). Autoregressive Distributed Lag (ARDL) cointegration technique: Application and interpretation. Journal of Statistical and Econometric Methods, 5(4), 63-91.

Ollivaud, P. \& Haxton, P. (2019). Making the most of tourism in Indonesia to promote sustainable regional development, OECD Economics Department Working Papers, No. 1535, OECD Publishing, Paris. https://doi.org/10.1787/c73325d9-en

Onafowora, O.A., \& Owoye, O. (2012). Modelling International Tourism Demand for the Caribbean. Tourism Economics, 18(1), 159180. https://doi.org/10.5367/te.2012.0102

Patsouratis, V., Frangouli, Z., \& Anastasopoulos, G. (2005). Competition in tourism among the Mediterranean countries. Applied Economics, 37(16), 1865-1870. https://doi.org/10.1080/00036840500217226

Peng, B., Song, H., Crouch, G.I., \& Witt, S.F. (2015). A Meta-Analysis of International Tourism Demand Elasticities. Journal of Travel Research, 54(5), 611-633. https://doi.org/10.1177/0047287514528283

Pesaran, M.H., \& Shin, Y. (1998). An autoregressive distributed-lag modelling approach to cointegration analysis. Econometric Society Monographs, 31, 371-413. https://doi.org/10.1017/CCOL0521633230.011

Pesaran, M.H., Shin, Y., \& Smith, R.J. (2001). Bounds testing approaches to the analysis of level relationships. Journal of Applied Econometrics, 16(3), 289-326. https://doi.org/10.1002/jae.616

Pujiharini, F., \& Ichihashi, M. (2016). The Impact of Visa-Free Entry on the Determinants of Inbound Tourism Demand in Indonesia (No. 6-5; IDEC DP2 Series). Hiroshima University, Graduate School for International Development and Cooperation (IDEC). https://ideas.repec.org/p/hir/idecdp/6-5.html

Purwomarwanto, Y.L., \& Ramachandran, J. (2015). Performance of tourism sector with regard to the global crisis-A comparative study between Indonesia, Malaysia and Singapore. The Journal of Developing Areas, 49(4), 325-339. https://doi.org/10.1353/jda.2015.0149

Rehman, A., Ma, H., Irfan, M., Ahmad, M., \& Traore, O. (2020). Investigating the Influence of International Tourism in Pakistan and Its Linkage to Economic Growth: Evidence From ARDL Approach. SAGE Open, 10(2), 215824402093252. https://doi.org/10.1177/2158244020932525

Salleh, N.H.M., Othman, R., \& Ramachandran, S. (2007). Malaysia's Tourism Demand from Selected Countries: The ARDL Approach to Cointegration. International Journal of Economics and Management, 1(3), 345-363.

Seetaram, N., Forsyth, P., \& Dwyer, L. (2016). Measuring price elasticities of demand for outbound tourism using competitiveness indices. Annals of Tourism Research, 56, 65-79. https://doi.org/10.1016/j.annals.2015.10.004

Smyth, R., Nielsen, I., \& Mishra, V. (2009). 'I've been to Bali too'(and I will be going back): Are terrorist shocks to Bali's tourist arrivals permanent or transitory? Applied Economics, 41(11), 1367-1378. https://doi.org/10.1080/00036840601019356

Song, H., \& Lin, S. (2010). Impacts of the Financial and Economic Crisis on Tourism in Asia. Journal of Travel Research, 49(1), 16-30. https://doi.org/10.1177/0047287509353190

Srinivasan, P., Kumar, P.S., \& Ganesh, L. (2012). Tourism and economic growth in Sri Lanka: An ARDL bounds testing approach. Environment and Urbanization Asia, 3(2), 397-405. https://doi.org/10.1177/0975425312473234

Wang, Y.S. (2009). The impact of crisis events and macroeconomic activity on Taiwan's international inbound tourism demand. Tourism Management, 30(1), 75-82. https://doi.org/10.1016/j.tourman.2008.04.010

Wahyuningtyas, N., Tanjung A., Idris I., \& Dewi, K. (2019). Disaster mitigation on cultural tourism in Lombok, Indonesia. GeoJournal of Tourism and Geosites, 27(4), 1227-1235. https://doi.org/10.30892/gtg.27409-428

Wasiaturrahma, \& Rohmawati, H. (2021). Multicollinearity in Tourism Demand Model: Evidence from Indonesia. Economics Development Analysis Journal, 10(1), 16.

Xie, J., \& Tveterås, S. (2020). Economic drivers for the Chinese tourists. Scandinavian Journal of Hospitality and Tourism, 20(2), 110125. https://doi.org/10.1080/15022250.2020.1734076

Yazdi, S.K., \& Khanalizadeh, B. (2017). Tourism demand: A panel data approach. Current Issues in Tourism, 20(8), 787-800. https://doi.org/10.1080/13683500.2016.1170772

Zhu, L., Lim, C., Xie, W., \& Wu, Y. (2018). Modelling tourist flow association for tourism demand forecasting. Current Issues in Tourism, 21(8), 902-916. https://doi.org/10.1080/13683500.2016.1218827

\footnotetext{
Article history: Received: 17.05.2021 Revised: 29.07.2021 Accepted: 03.09.2021 Available online: 23.09.2021
} 